\title{
The impact of the COVID-19 pandemic on Sexually Transmitted Infections surveillance data: incidence drop or artefact?
}

\author{
Alexis Sentís ${ }^{1,2,3,4+}$, Albert Prats-Uribe ${ }^{5 \dagger}$, Evelin López-Corbeto ${ }^{1,2}$, Marcos Montoro-Fernandez ${ }^{1}$, \\ Daniel Kwakye Nomah ${ }^{1,6}$, Patrícia Garcia de Olalla ${ }^{2,7}$, Lilas Mercuriali ${ }^{7}$, Núria Borrell ${ }^{8}$, Víctor Guadalupe-Fernández ${ }^{9}$, \\ Juliana Reyes-Urueña $a^{1,2^{*}}$, Jordi Casabona ${ }^{1,2,6}$ and Catalan HIV and STI Surveillance Group
}

\begin{abstract}
Background: Before the COVID-19 pandemic, Sexually transmitted infections (STIS) were increasing in Europe, and Spain and Catalonia were not an exception. Catalonia has been one of the regions with the highest number of COVID-19 confirmed cases in Spain. The objective of this study was to estimate the magnitude of the decline, due to the COVID-19 pandemic, in the number of STI confirmed cases in Catalonia during the lockdown and deescalation phases.

Methods: Interrupted time series analysis was performed to estimate the magnitude of decline in the number of STI reported confirmed cases - chlamydia, gonorrhoea, syphilis, and lymphogranuloma venereum- in Catalonia since lockdown with historical data, from March 13th to August 1st 2020, comparing the observed with the expected values.

Results: We found that since the start of COVID-19 pandemic the number of STI reported cases was 51\% less than expected, reaching an average of 56\% during lockdown (50\% and $45 \%$ during de-escalation and new normality) with a maximum decrease of $72 \%$ for chlamydia and minimum of $22 \%$ for syphilis. Our results indicate that fewer STIs were reported in females, people living in more deprived areas, people with no previous STI episodes during the last three years, and in the HIV negative.
\end{abstract}

Conclusions: The STI notification sharp decline was maintained almost five months after lockdown started, well into the new normality. This fact can hardly be explained without significant underdiagnosis and underreporting. There is an urgent need to strengthen STI/HIV diagnostic programs and services, as well as surveillance, as the pandemic could be concealing the real size of the already described re-emergence of STIs in most of the European countries.

Keywords: Public health, Surveillance, communicable diseases, Sexually transmitted infections, Interrupted time series, COVID-19, Lockdown, Trends, Epidemiology

\footnotetext{
* Correspondence: jmreyes@iconcologia.net

${ }^{\dagger}$ Alexis Sentís and Albert Prats-Uribe contributed equally to this work.

${ }^{1}$ Centre of epidemiological studies on sexually transmitted infections and

AIDS of Catalonia (CEEISCAT). Department of Health. Generalitat of Catalonia,

Badalona, Spain

${ }^{2}$ Spanish Consortium for Research on Epidemiology and Public Health

(CIBERESP), Instituto de Salud Carlos III, Madrid, Spain

Full list of author information is available at the end of the article
}

\section{$\triangle B M C$}

C C The Author(s). 2021 Open Access This article is licensed under a Creative Commons Attribution 4.0 International License, which permits use, sharing, adaptation, distribution and reproduction in any medium or format, as long as you give appropriate credit to the original author(s) and the source, provide a link to the Creative Commons licence, and indicate if changes were made. The images or other third party material in this article are included in the article's Creative Commons licence, unless indicated otherwise in a credit line to the material. If material is not included in the article's Creative Commons licence and your intended use is not permitted by statutory regulation or exceeds the permitted use, you will need to obtain permission directly from the copyright holder. To view a copy of this licence, visit http://creativecommons.org/licenses/by/4.0/ The Creative Commons Public Domain Dedication waiver (http://creativecommons.org/publicdomain/zero/1.0/) applies to the data made available in this article, unless otherwise stated in a credit line to the data. 


\section{Background}

Before the coronavirus disease 2019 (COVID-19) pandemic, the number of new cases of mandatory notifiable sexually transmitted infections (STIs) was increasing in many European countries. Catalonia also had a pronounced rise of chlamydia, gonorrhoea, syphilis and lymphogranuloma venereum (LGV). For the last five years, Catalonia presented the highest incidence rates of Spain in all mandatory notifiable STIs, with a $20 \%$ annual increase. The rates were highest among males who have sex with males (MSM) and young adults, mostly females aged between 20 to 24 [1]. STIs represent one of the highest burdens of disease in adolescents and young females, leading to miscarriage, pelvic inflammatory disease, and increased risk to acquire human immunodeficiency virus (HIV) [2-4]. According to data published by the Government of Catalonia, the COVID-19 pandemic hit Catalonia harshly, with 676.863 confirmed cases and 22.124 deaths by May 24th, 2021, with one of the highest number of confirmed cases in Spain [5, 6]. On March 13, the Spanish government announced a countrywide lockdown, with a mandatory stay at home ordinance, with some exceptions, such as purchasing food or medicine, going to work or attending to emergencies. Visiting intimate partners were not included in the exceptions [7]. The combined effects of the lockdown and the unprecedented pressure on health systems might have reduced the capacity to detect STIs, potentially leading to increased transmission and more severe sequelae, or a decrease in the incidence because of less exposure. The objective of this study was to estimate the magnitude of the decline, due to the COVID-19 pandemic, in the number of STI reported confirmed cases in Catalonia during the lockdown and de-escalation phases comparing the observed and expected values.

\section{Methods}

\section{The Catalan HIV/STI surveillance systems}

We used epidemiological data from all STI confirmed cases reported to the Catalan HIV/STI Registry of Catalonia [8] through the Epidemiological Repository of Catalonia (REC), an electronic database that collects data reported from health care professionals and laboratories by means of standardized notification forms and epidemiological questionnaires, both electronically or in paper. According to the mandatory notification of diseases and outbreaks Catalan regulation (Health Department of Government of Catalonia article 13 of law 67/ 2010, 25 May 2010), nominal notification of syphilis, gonorrhoea, and LGV cases has been mandatory since 2007 and chlamydia since 2015; the notification of HIV cases was voluntary between 2001 and 2010 when it also became mandatory and nominal. The European Centre for Disease Prevention and Control (ECDC) guidelines are used for case definition criteria and all reported cases are reviewed by epidemiologists from the Epidemiological Surveillance Network of Catalonia (XVEC) to ensure completeness and validity of the data.

\section{Study variables}

Sex, age group, and country of birth were collected from REC. Deprivation index (calculated by the Agency of Health Quality and Assessment of Catalonia) was based on the patient area of residence and categorized in quintiles, with the first quintile being the least deprived [9]. Multiple episodes by the same STI in the same individual were considered reinfections when evidence of it, proper treatment, and minimum length of time between reports existed. Time periods were defined according to specific STI treatment duration and follow up recommendations, being 364, 29, 119 and 119 days respectively for syphilis, gonorrhoea, chlamydia and LGV [10]. HIV status was confirmed checking the HIV status among individuals who had one single or more STI episodes during the study period within the Catalan HIV/STI Registry of Catalonia where previous and simultaneous HIV coinfections can be identified.

\section{Interrupted time series and data analysis}

We analysed STI reported cases between August 1st 2017 and August 1st 2020 in Catalonia. We have included three years of follow-up not only in order to estimate the reported cases we would have had from lockdown - from March 13th to August 1st, 2020- but also to capture potential seasonal or cyclic changing patterns. For each of the mentioned variables, among the STI reported confirmed cases, the total number and its distribution in the respective categories were calculated, before lockdown, during lockdown (March 13th to April 27th), on de-escalation phases (April 28th until June 21st), and during the new normality phase (since June 22nd). The main objective of the de-escalation plan was to ensure maintaining the protection of public health while gradually recovering the common daily life and economic activities after the lockdown. This transition to a "new normality" was gradual, asymmetrical, and coordinated with the autonomous communities [11]. We used these dates as change points for an interrupted time series (ITS) analysis of daily STI reported cases (overall and separately for each of them). Reported cases were modelled as autoregressive integrated moving average (ARIMA) processes to estimate expected number of STI reported cases in each specific study period since lockdown based on pre-lockdown data. We calculated the overall drop in number of STI reported cases, to estimate the magnitude of the decline in STI reported cases with historical data comparing the observed and expected values. 


\section{Results}

When comparing with pre-lockdown period's data, the STI reported cases per day decreased by almost $50 \%$ in all three COVID-19 related study periods: during lockdown, de-escalation and new normality periods (from
43.8 STI reported cases/day pre-lockdown to $22.2,23.4$ and 27.9 respectively). The proportion of syphilis and LGV slightly increased (from $15 \%$ and $1.7 \%$ prelockdown) among the overall STI reported cases in all three COVID-19 related study periods (respectively in

Table 1 Epidemiological characteristics of the STI reported confirmed cases during the different study periods ${ }^{\mathrm{a}}$ in Catalonia, August 1st 2017 to August 1st 2020

\begin{tabular}{|c|c|c|c|c|c|c|c|c|c|c|}
\hline \multirow{3}{*}{$\begin{array}{l}\text { Number of reported cases } \\
\text { Days, } n^{\circ} \text { reported cases/days }\end{array}$} & \multirow{2}{*}{\multicolumn{2}{|c|}{$\frac{\text { Total }}{N=45,181}$}} & \multirow{2}{*}{\multicolumn{2}{|c|}{$\begin{array}{l}\text { Pre-lockdown } \\
N=41,802\end{array}$}} & \multirow{2}{*}{\multicolumn{2}{|c|}{$\begin{array}{l}\text { Lockdown } \\
N=997\end{array}$}} & \multirow{2}{*}{\multicolumn{2}{|c|}{$\begin{array}{l}\text { De-escalation Phases } \\
N=1266\end{array}$}} & \multirow{2}{*}{\multicolumn{2}{|c|}{$\frac{\text { New Normality }}{N=1116}$}} \\
\hline & & & & & & & & & & \\
\hline & 1096 & $\overline{41.2}$ & 954 & 43.8 & 45 & 22.2 & 54 & 23.4 & 40 & 27.9 \\
\hline & $\mathbf{N}$ & $\%$ & $\mathbf{N}$ & $\%$ & $\mathbf{N}$ & $\%$ & $\mathbf{N}$ & $\%$ & $\mathbf{N}$ & $\%$ \\
\hline \multicolumn{11}{|l|}{ STI } \\
\hline Chlamydia & 23,095 & 51.1 & 21,463 & 51.3 & 472 & 47.3 & 611 & 48.3 & 549 & 49.1 \\
\hline Gonorrhoea & 14,406 & 31.9 & 13,340 & 31.9 & 329 & 33.0 & 398 & 31.4 & 339 & 30.3 \\
\hline $\mathrm{LGV}^{\mathrm{b}}$ & 815 & 1.8 & 723 & 1.7 & 28 & 2.8 & 29 & 2.3 & 35 & 3.1 \\
\hline Syphilis & 6865 & 15.2 & 6276 & 15.0 & 168 & 16.9 & 228 & 18.0 & 193 & 17.3 \\
\hline \multicolumn{11}{|l|}{ Sex } \\
\hline Females & 17,860 & 39.5 & 16,679 & 39.9 & 340 & 34.1 & 453 & 35.8 & 388 & 34.7 \\
\hline Males & 27,321 & 60.5 & 25,123 & 60.1 & 657 & 65.9 & 813 & 64.2 & 728 & 65.2 \\
\hline Age (mean, $S^{c}$ ) & 31.7 & 11.1 & 31.7 & 11.1 & 31.9 & 10.6 & 32.5 & 11.9 & 32.3 & 11.4 \\
\hline \multicolumn{11}{|l|}{ Age group } \\
\hline$<20$ & 5776 & 12.8 & 5384 & 12.9 & 113 & 11.3 & 154 & 12.2 & 125 & 11.2 \\
\hline 20 to 29 & 17,334 & 38.4 & 16,052 & 38.4 & 376 & 37.7 & 477 & 37.7 & 429 & 38.4 \\
\hline 30 to 39 & 12,076 & 26.7 & 11,180 & 26.7 & 282 & 28.3 & 321 & 25.4 & 293 & 26.3 \\
\hline 40 to 49 & 6702 & 14.8 & 6177 & 14.8 & 155 & 15.5 & 198 & 15.6 & 172 & 15.4 \\
\hline 50 to 59 & 2334 & 5.20 & 2124 & 5.1 & 56 & 5.6 & 83 & 6.6 & 71 & 6.4 \\
\hline$\geq 60$ & 959 & 2.1 & 885 & 2.1 & 15 & 1.5 & 33 & 2.6 & 26 & 2.3 \\
\hline \multicolumn{11}{|l|}{ Deprivation index } \\
\hline First quintile & 11,221 & 24.8 & 10,288 & 24.6 & 286 & 28.70 & 344 & 27.20 & 303 & 27.2 \\
\hline Second quintile & 8133 & 18.0 & 7436 & 17.8 & 214 & 21.50 & 240 & 19.00 & 243 & 21.8 \\
\hline Third quintile & 5329 & 11.8 & 4915 & 11.8 & 135 & 13.50 & 155 & 12.20 & 124 & 11.1 \\
\hline Fourth quintile & 6150 & 13.6 & 5717 & 13.7 & 106 & 10.60 & 193 & 15.20 & 134 & 12.0 \\
\hline Fifth quintile & 8246 & 18.3 & 7618 & 18.2 & 185 & 18.60 & 236 & 18.60 & 207 & 18.5 \\
\hline Missing & 6102 & 13.5 & 5828 & 13.9 & 71 & 7.10 & 98 & 7.70 & 105 & 9.4 \\
\hline \multicolumn{11}{|l|}{ Country of birth } \\
\hline Spain & 13,861 & 30.7 & 13,316 & 31.9 & 136 & 13.6 & 207 & 16.4 & 202 & 18.1 \\
\hline Others & 4913 & 10.9 & 4785 & 11.4 & 24 & 2.4 & 56 & 4.4 & 48 & 4.3 \\
\hline Missing & 26,407 & 58.4 & 23,701 & 56.7 & 837 & 84.0 & 1003 & 79.2 & 866 & 77.6 \\
\hline \multicolumn{11}{|l|}{ Reinfeccion } \\
\hline No & 39,619 & 87.7 & 36,893 & 88.3 & 838 & 84.1 & 1019 & 80.5 & 869 & 77.9 \\
\hline Yes & 5562 & 12.3 & 4909 & 11.7 & 159 & 15.9 & 247 & 19.5 & 247 & 22.1 \\
\hline \multicolumn{11}{|l|}{ HIV status } \\
\hline Negative & 42,809 & 94.8 & 39,628 & 94.8 & 937 & 94.0 & 1196 & 94.5 & 1048 & 93.9 \\
\hline Positive & 2372 & 5.2 & 2174 & 5.2 & 60 & 6.0 & 70 & 5.5 & 68 & 6.1 \\
\hline
\end{tabular}

a Pre-lockdown: from August 1st 2017 to March 12th 2020, lockdown: from March 13th 2020 to April 27 ${ }^{\text {th }} 2020$, de-escalation phases: from April 28th 2020 to June 21st 2020, new normality: from June ${ }^{22 n d} 2020$ to August 1st 2020;

bLGV: Lymphogranuloma venereum;

'SD: Standard deviation 
the three study periods to $16.9 \%, 18 \%$, and $17.3 \%$ for syphilis and $2.8 \%, 2.3 \%$ and $3.1 \%$ for LGV) meanwhile gonorrhoea and chlamydia had a small decrease (from $31.9 \%$ and $51.3 \%$ pre-lockdown to $30.3 \%$ and $49.1 \%$ in the "new normality" period for gonorrhoea and for chlamydia respectively). In addition, the proportion of STI reported cases from females was reduced when compared to males (approximately 5\% between prelockdown and new normality periods). STI reported cases that came from areas with higher socioeconomic status increased by $5 \%$ over post-lockdown periods (see Table 1). The proportion of missing data for country of birth was high during all the different study periods and increased by $25 \%$ during lockdown (from $56.7 \%$ missing values in pre-lockdown data to $84 \%$ during lockdown). The proportion of STI reported cases in people coinfected by HIV, as well as the proportions of STI reported cases considered as reinfections, increased from prelockdown to new normality periods $(5.2 \%$ to $6.1 \%$ and
$11.7 \%$ to $22.2 \%$, respectively). The proportion of reported cases in each age groups was similar when comparing the study periods with previous or historical data (see Table 1).

In the ITS (see Table 2, Fig. 1, and supplemental material, figure S1-S4), we observed how the number of all STI reported cases were only $49 \%$ of the expected number (decrease of $-51 \%$, confidence interval (CI): $-59 \%$ to $-38 \%$ ), based on pre-lockdown data (since August 1st 2020), with variations in the different study periods; being only $44 \%$ of the expected reported cases during lockdown (decrease of $-56 \%$, CI: $-63 \%$ to $-46 \%$ ) and slowly increasing to $55 \%$ of the expected since the new normality began on June 22nd (decrease of $-45 \%, \mathrm{CI}$ : $-54 \%$ to $-30 \%)$. When analysing the results by type of infection we found that chlamydia's reported cases which represent more than $50 \%$ of all STI reported cases, had the highest decrease in notification over post-lockdown periods, with observed reported cases reaching only $28 \%$ of

Table 2 Comparing observed and expected number of STI reported confirmed cases during the different study periods ${ }^{a}$ in Catalonia, August 1st 2017 to August 1st 2020

\begin{tabular}{|c|c|c|c|c|c|c|c|c|c|c|c|}
\hline \multirow{2}{*}{ All STIs } & \multirow{2}{*}{$\begin{array}{l}\text { Periods } \\
\text { Pre-lockdown }\end{array}$} & \multirow{2}{*}{$\begin{array}{l}\text { observed } \\
41,814\end{array}$} & \multirow[t]{2}{*}{ expected } & \multirow[t]{2}{*}{ upper $\mathrm{Cl}^{\mathrm{b}}$} & \multirow[t]{2}{*}{ lower $\mathrm{Cl}^{\mathrm{b}}$} & \multicolumn{2}{|c|}{ difference } & \multicolumn{2}{|c|}{ upper $\mathrm{Cl}^{\mathrm{b}}$} & \multicolumn{2}{|c|}{ lower $\mathrm{Cl}^{\mathrm{b}}$} \\
\hline & & & & & & & & & & & \\
\hline & Lockdown & 997 & 2264 & 2681 & 1846 & -1267 & $-56 \%$ & -1684 & $-63 \%$ & -849 & $-46 \%$ \\
\hline & De-escalation & 1266 & 2546 & 3078 & 2015 & -1280 & $-50 \%$ & -1812 & $-59 \%$ & -749 & $-37 \%$ \\
\hline & New Normality & 1116 & 2026 & 2446 & 1606 & -910 & $-45 \%$ & -1330 & $-54 \%$ & -490 & $-30 \%$ \\
\hline & Total & 3379 & 6836 & 8205 & 5467 & -3457 & $-51 \%$ & -4826 & $-59 \%$ & -2088 & $-38 \%$ \\
\hline \multirow[t]{5}{*}{ Chlamydia } & Pre-lockdown & 21,463 & & & & & & & & & \\
\hline & Lockdown & 472 & 1607 & 1731 & 1483 & -1135 & $-71 \%$ & -1259 & $-73 \%$ & -1011 & $-68 \%$ \\
\hline & De-escalation & 611 & 2376 & 2535 & 2216 & -1765 & $-74 \%$ & -1924 & $-76 \%$ & -1605 & $-72 \%$ \\
\hline & New Normality & 549 & 1870 & 1997 & 1743 & -1321 & $-71 \%$ & -1448 & $-73 \%$ & -1194 & $-68 \%$ \\
\hline & Total & 1632 & 5853 & 6264 & 5442 & -4221 & $-72 \%$ & -4632 & $-74 \%$ & -3810 & $-70 \%$ \\
\hline \multirow[t]{5}{*}{ Gonorrhoea } & Pre-lockdown & 13,340 & & & & & & & & & \\
\hline & Lockdown & 329 & 747 & 889 & 605 & -418 & $-56 \%$ & -560 & $-63 \%$ & -276 & $-46 \%$ \\
\hline & De-escalation & 398 & 857 & 1037 & 678 & -459 & $-54 \%$ & -639 & $-62 \%$ & -280 & $-41 \%$ \\
\hline & New Normality & 339 & 670 & 812 & 529 & -331 & $-49 \%$ & -473 & $-58 \%$ & -190 & $-36 \%$ \\
\hline & Total & 1066 & 2275 & 2738 & 1812 & -1209 & $-53 \%$ & -1672 & $-61 \%$ & -746 & $-41 \%$ \\
\hline \multirow[t]{5}{*}{ Syphilis } & Pre-lockdown & 6276 & & & & & & & & & \\
\hline & Lockdown & 168 & 250 & 337 & 164 & -82 & $-33 \%$ & -169 & $-50 \%$ & 4 & $2 \%$ \\
\hline & De-escalation & 228 & 284 & 392 & 177 & -56 & $-20 \%$ & -164 & $-42 \%$ & 51 & $29 \%$ \\
\hline & New Normality & 193 & 218 & 302 & 134 & -25 & $-11 \%$ & -109 & $-36 \%$ & 59 & $44 \%$ \\
\hline & Total & 589 & 753 & 1030 & 475 & -164 & $-22 \%$ & -441 & $-43 \%$ & 114 & $24 \%$ \\
\hline \multirow[t]{5}{*}{ LGV $^{c}$} & Pre-lockdown & 723 & & & & & & & & & \\
\hline & Lockdown & 28 & 54 & 62 & 47 & -26 & $-48 \%$ & -34 & $-55 \%$ & -19 & $-40 \%$ \\
\hline & De-escalation & 29 & 80 & 89 & 71 & -51 & $-64 \%$ & -60 & $-67 \%$ & -42 & $-59 \%$ \\
\hline & New Normality & 35 & 56 & 63 & 49 & -21 & $-38 \%$ & -28 & $-45 \%$ & -14 & $-29 \%$ \\
\hline & Total & 92 & 191 & 214 & 167 & -99 & $-52 \%$ & -122 & $-57 \%$ & -75 & $-45 \%$ \\
\hline
\end{tabular}

aPre-lockdown: from August 1st 2017 to March 12th 2020, lockdown: from March 13th 2020 to April 27 ${ }^{\text {th }} 2020$, de-escalation phases: from April 28th 2020 to June 21st 2020, new normality: from June 22 nd 2020 to August 1st 2020; bCl, confidence interval; CLGV, lymphogranuloma venereum 


\section{All STD}

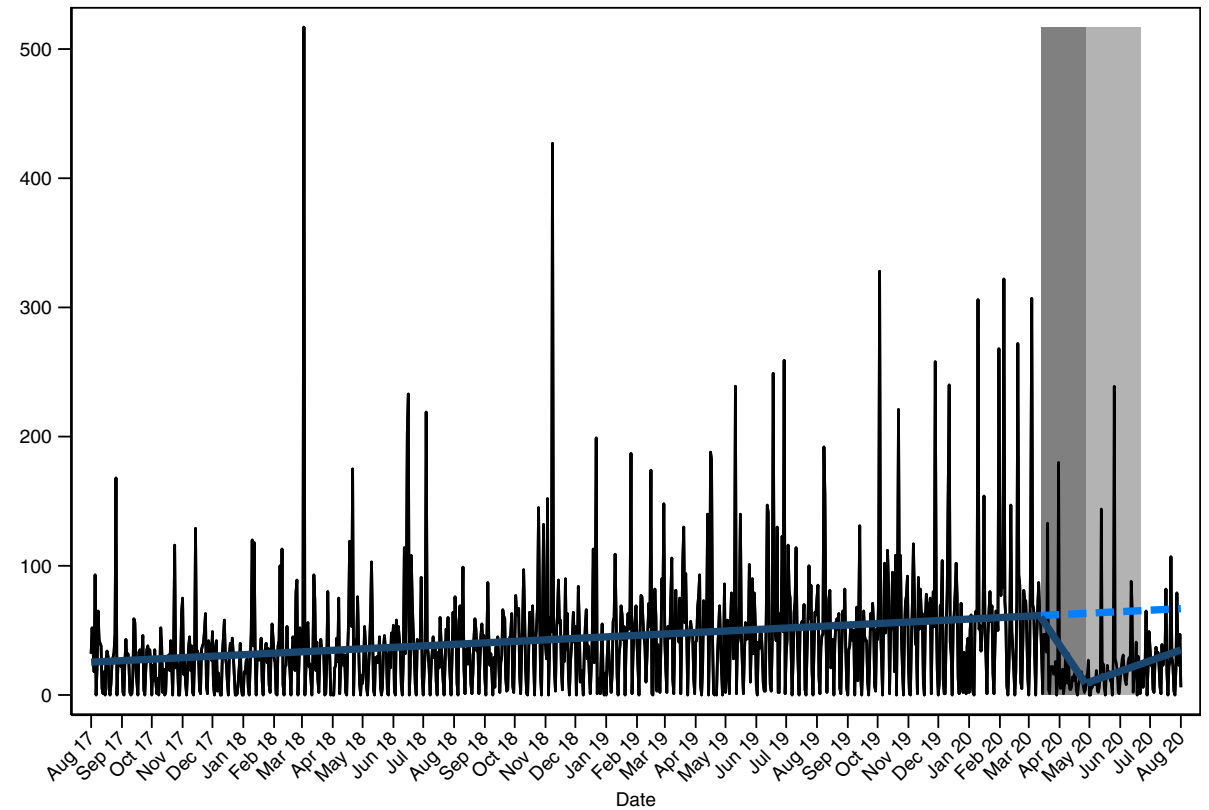

Fig. 1 Observed and expected time series trends of daily STI reported confirmed cases in Catalonia during the COVID-19 pandemic, August 1st 2017 - August 1st 2020 (dark grey: lockdown, light grey: de-escalation phases)

the expected values. Conversely, we observed that the decrease of syphilis reported cases was lower, with observed reported cases reaching $78 \%$ of those expected (see Table 2 and supplemental material, figure S1 and figure S3).

\section{Discussion}

We found that since the start of COVID-19 pandemic the number of STI reported cases was $51 \%$ less than expected, reaching an average of 56\% during lockdown (50 and $45 \%$ during de-escalation and new normality) with a maximum decrease of $72 \%$ for chlamydia and minimum of $22 \%$ for syphilis. Our results indicate that STIs were less reported in females, people living in more deprived areas, people with no previous STI episodes during the last three years, and without HIV infection.

We hypothesize that the decline in the number of STI reported cases was higher in females based on the annual STI notification rates in the region where chlamydia has been usually higher among females and syphilis among males [1]. STIs, including chlamydia infection are predominantly asymptomatic in females, and are detected primarily through screening. During lockdown, mobility restrictions may have decreased healthcare seeking behaviour in asymptomatic individuals with high-risk exposures. This decrease could be even greater for people living in more deprived areas. Additionally, people who already visited sexual health care for previous STI episodes in the last three years, or HIV positive are more likely to seek health care.

To the best of our knowledge, few analysis have described the estimated magnitude and impact of the COVID-19 pandemic on the expected number of STIs compared to the most recent historical data. Although few articles have analysed STI incidences during lockdown, some authors argue that the plausible decrease of sexually relations during the COVID-19 pandemic may partially explain the apparent drop in the number of STI incidence [12-14]. In spite of these, different stakeholders have started raising awareness about disruptions in sexual health services including STI and HIV testing and detection $[15,16]$. Moreover, it has been estimated that in the Atlanta (State of Georgia, United States), if sexual behaviour rebounds while service interruption persists, cases will increase in hundreds for HIV and in thousands for STIs for the next five years [17]. Berzkalns et al. performed a study in King County (State of Washington, United States) where the number of sexual health clinic visits decreased 55\% during lockdown. Although after lockdown numbers returned to prelockdown values, around lockdown, from January-July 2020, the number of STIs diagnosed declined differently depending on the STI, from $9 \%$ for gonorrhoea to $22 \%$ for early latent syphilis [18]. They suggested that a real decline may have happened, but the larger decline in asymptomatic STIs probably indicates decreased 
screening. Similarly, Chow et al. described that, although a relevant decrease in the total number of consultations occurred in the Melbourne Sexual Health Centre during the lockdown, for more severe conditions such as pelvic inflammatory disease or infectious syphilis, a similar number of consultations to the pre-lockdown period was observed [19]. Recently, an article from the EuroTEST COVID-19 impact assessment consortium described that, among 34 countries in the World Health Organization (WHO) European Region and in different testing settings, 95\% of them declared to have tested less than half the expected number of people between March and May 2020, a decline that continued at lesser degrees until August 2020 [20]. Then, this decline probably is due to the effect of a combination of factors; changes in the people's behaviour, sexual relationships or fear of visiting a health care setting [21], less available resources to diagnose and notify STIs (including human resources), and surveillance systems which were not able to integrate the immediate reaction to a pandemic, while coping with their regular surveillance activities.

\section{Conclusions}

Our results showed that the STI notification sharp decline was maintained almost five months since lockdown, well into the new normality. This can hardly be explained without significant underdiagnoses and underreporting. The gradual increase in the number of STI reported cases that we observed after lockdown may be pointing out the possibility that lockdowns did not completely disrupt STI transmission. As discussed in the present article, with the available current scientific evidence, it seems that the observed decrease in the number of STI reported cases during the current COVID-19 pandemic is probably due to a combination of factors. More research is needed in order to disentangle the specific role and relevance that has had underdiagnosis, underreporting, and the decrease in sexual risk activities and other potential factors in this decline. Finally, we truly believe that there is an urgent need to strengthen STI/HIV diagnostic programs and services, as well as surveillance, as the pandemic could be concealing the real size of the already described re-emergence of STIs $[22]$.

\footnotetext{
Abbreviations

COVID-19: The coronavirus disease 2019; STI: Sexually transmitted infections; LGV: Lymphogranuloma venereum; MSM: Males who have sex with males; HIV: Human immunodeficiency virus; REC: Epidemiological repository of Catalonia; XVEC: The Epidemiological Surveillance Network of Catalonia; ECDC: European Centre for Disease Prevention and Control; ITS: Interrupted time series; ARIMA: Autoregressive integrated moving average;

$\mathrm{Cl}$ : Confidence interval; WHO: World Health Organization
}

\section{Supplementary Information}

The online version contains supplementary material available at https://doi. org/10.1186/s12889-021-11630-x.

Additional file 1: Fig. S1. Expected and observed time series trends of daily Chlamydia reported confirmed cases in Catalonia, August 1st 2017 August 1st 2020 (dark grey: lockdown, light grey: de-escalation phases). Fig. S2. Expected and observed time series trends of daily Gonorrhoea reported confirmed cases in Catalonia, August 1st 2017 - August 1st 2020 (dark grey: lockdown, light grey: de-escalation phases). Fig. S3. Expected and observed time series trends of daily Syphilis reported confirmed cases in Catalonia, August 1st 2017 - August 1st 2020 (dark grey: lockdown, light grey: de-escalation phases). Fig. S4. Expected and observed time series trends of daily lymphogranuloma venerum (LGV) reported cases in Catalonia, August 1st 2017 - August 1st 2020 (dark grey: lockdown, light grey: de-escalation phases).

\section{Acknowledgements}

We thank all the reporting physicians and people working in HIV/STI surveillance in Catalonia who have contributed in the collection and quality of the information in the surveys including the Catalan HIV and STI Surveillance Group, which is composed by the following members: A Sentís, E López, V Gonzalez, R Lugo, MP Bonamusa, J Reyes, J Casabona (Centre d'Estudis Epidemiològics sobre les Infeccions de Transmissió Sexual i Sida de Catalunya); P Garcia de Olalla, Lilas Mercuriali, R Clos, R Rodriguez, M Masdeu, M Ros, P Simon, I Avellaneda, A Artigas, C Rius (Servei d'Epidemiologia de I'Agència de Salut Pública de Barcelona); M Company, M Danés, N Camps (Servei de Vigilància Epidemiològica i Resposta a Emergències de Salut Pública a Girona); RM Vileu, G Ferrús, N Borrell, S Minguell (Servei de Vigilància Epidemiològica i Resposta a Emergències de Salut Pública a Tarragona); J Ferràs (Servei de Vigilància Epidemiològica i Resposta a Emergències de Salut Pública a Terres de l'Ebre); I Parrón (Servei de Vigilància Epidemiològica i Resposta a Emergències de Salut Pública al Barcelonès Nord i Maresme); I Mòdol, A Martinez, P Godoy (Servei de Vigilància Epidemiològica i Resposta a Emergències de Salut Pública a Lleida); MA Tarrès, J Pérez, M Boldú, I Barrabeig (Servei de Vigilància Epidemiològica i Resposta a Emergències de Salut Pública a Barcelona Sud); E Donate, L Clotet, MR Sala (Servei de Vigilància Epidemiològica i Resposta a

Emergències de Salut Pública al Vallès Occidental i Vallès Oriental); M Carol, V Guadalupe-Fernández (Servei de Vigilància Epidemiològica i Resposta a Emergències de Salut Pública a Catalunya Central) and J Mendioroz, P Ciruela, G Carmona, R Mansilla, JL Martínez, S Hernández (Subdirecció General de Vigilància Epidemiològica i Resposta a Emergències de Salut Pública, Agència de Salut Pública de Catalunya).

\section{Authors' contributions}

AS and JC conceptualized the paper. AS and APU designed the study. MMF cleaned the database. AS and APU reviewed scientific literature, performed the statistical analysis, and drafted the manuscript. AS, APU, JC, JRU, ELC, DN, PG, LM, NB, VGF, and Catalan HIV and STI Surveillance Group interpreted the results and contributed to improving the content in the sections of their expertise. The Catalan HIV and STI Surveillance Group managed and verified all the reported cases. All the authors collaborated in the critical review and approved the final manuscript.

\section{Funding}

AP-U is supported by Fundacion Alfonso Martin Escudero and the Medical Research Council (grant numbers MR/K501256/1, MR/N013468/1).

\section{Availability of data and materials}

Public access to the database(s) is close. Data sharing is not possible because patients' individual privacy could be compromised. Although data was deidentified to be handled, some aggregated results could be sensitive when communicated at a population level. For this reason, the analysis and dissemination of this data is handled by public health authorities with surveillance responsibilities and avoiding disaggregation by small geographical areas. 


\section{Declarations}

\section{Ethics approval and consent to participate}

Ethics approval by an ethics committee was not necessary according to national regulations; Data from mandatory notifiable disease in REC application were handled according to Spanish Organic Law 3/2018 on Data protection and guarantee of Digital Rights, and Law 33/2011 on General Public Health. Patient information was anonymized and deidentified before handed over for analysis and therefore no informed consent was required. Patients were not directly involved in this study; only data coming from notifiable disease surveillance systems were used which did not imply any additional approval requirements. Data was handled anonymously by researchers from the Centre of epidemiological studies on sexually transmitted infections and AIDS of Catalonia (CEEISCAT) (Department of Health, Generalitat of Catalonia, Spain), which has the mandate of collect, analyse and disseminate STI/HIV surveillance data in Catalonia, as part of their routine functions.

\section{Consent for publication}

Not applicable.

\section{Competing interests}

The authors declare that they have no competing interests.

\section{Author details}

${ }^{1}$ Centre of epidemiological studies on sexually transmitted infections and AIDS of Catalonia (CEEISCAT). Department of Health. Generalitat of Catalonia, Badalona, Spain. ${ }^{2}$ Spanish Consortium for Research on Epidemiology and Public Health (CIBERESP), Instituto de Salud Carlos III, Madrid, Spain. ${ }^{3}$ Pompeu Fabra University (UPF), Barcelona, Spain. ${ }^{4}$ Epiconcept, Epidemiology Department, Paris, France. ${ }^{5}$ Centre for Statistics in Medicine, Botnar Research Centre, NDORMS, University of Oxford, Oxford, UK. ${ }^{6}$ Department of Paediatrics, Obstetrics and Gynecology and Preventive Medicine, Universitat Autónoma de Barcelona, Badalona, Spain. ${ }^{7}$ Epidemiological Service of Public Health Agency of Barcelona, Barcelona, Spain. ${ }^{8}$ Epidemiological Surveillance and Response to Public Health Emergencies Service in Tarragona Camp, Agency of Public Health of Catalonia, Generalitat of Catalonia, Tarragona, Spain. ${ }^{9}$ Epidemiological Surveillance and Response to Public Health Emergencies Service in Central Catalonia, Agency of Public Health of Catalonia, Generalitat of Catalonia, Manresa, Spain.

\section{Received: 17 October 2020 Accepted: 13 August 2021}

\section{Published online: 07 September 2021}

\section{References}

1. Centre of epidemiological studies on sexually transmitted infections and AIDS of Catalonia (CEEISCAT). Vigilància epidemiològica de les infeccions de transmissió sexual a Catalunya. 2019. www.ceeiscat.cat. Accessed 7 Aug 2020.

2. STD Facts - STDs \& Pregnancy Detailed Fact Sheet. https://www.cdc.gov/ std/pregnancy/stdfact-pregnancy-detailed.htm. Accessed 24 May 2021.

3. WHO. Sexually transmitted infections (STIs). https://www.who.int/news room/fact-sheets/detail/sexually-transmitted-infections-(stis). Accessed 7 Aug 2020.

4. HIV/AIDS \& STDs. https://www.cdc.gov/std/hiv/default.htm. Accessed 22 Feb 2021.

5. Situación de COVID-19 en España a 19 de mayo de 2021. Equipo COVID-19. RENAVE. CNE. CNM (ISCIII). Informe n ${ }^{\circ}$ 79. https://www.isciii.es/QueHa cemos/Servicios/VigilanciaSaludPublicaRENAVE/EnfermedadesTransmisibles/ Documents/INFORMES/Informes COVID-19/INFORMES COVID-19 2021/ Informe $\mathrm{n}^{\circ}$ 79. Situación de COVID-19 en España a 19 de mayo de 2021.pdf. Accessed 24 May 2021

6. Generalitat de Catalunya, Departament de Salut. Dades COVID https://da descovid.cat/. Accessed 24 May 2021.

7. Real Decreto 463/2020, de 14 de marzo, por el que se declara el estado de alarma para la gestión de la situación de crisis sanitaria ocasionada por el COVID-19. Boletin oficial del estado. Sec. I. Pág. 25390. https://www.boe.es. Accessed 24 May 2021

8. SIVES 2015 - Sistema Integrat de Vigilància Epidemiològica de la SIDANIH/ ITS a Catalunya. 2015. https://scientiasalut.gencat.cat/bitstream/handle/113
51/3418/informe_SIVES_2015_informe_epidemiologic_CEEISCAT_2015.pdf. pdf?sequence=1\&isAllowed=y. Accessed 27 Mar 2021.

9. Agency for Health Quality and Assessment of Catalonia. Nou indicador socioeconòmic per al finançament de les ABS. Observatori del Sistema de Salut de Catalunya. 2017. http://observatorisalut.gencat.cat/ca/observatoridesigualtats-salut/indicador_socioeconomic_2015/. Accessed 6 Aug 2020.

10. Centers for Disease Control and Prevention. Sexually Transmitted Diseases Treatment Guidelines, 2015. MMWR Recomm Rep 2015; 64 (No. RR-3): 33, 37, 57, 64.https://www.cdc.gov/std/tg2015/toc.htm. Accessed 2 Sep 2020.

11. Plan para la transición hacia una nueva normalidad. 28 de abril 2020. Gobierno de España. Ministerio de Sanidad. https://www.lamoncloa.gob.es/ consejodeministros/resumenes/Documents/2020/PlanTransicionNueva Normalidad.pdf. Accessed 25 May 2021.

12. Mohamed A, Hammoud LM, et al. Physical distancing due to COVID-19 disrupts sexual behaviours among gay and bisexual men in Australia. JAIDS J Acquir Immune Defic Syndr. https://pubmed.ncbinlm.nih.gov/32740374/.

13. Alpalhão $M$, Filipe $P$. The impacts of isolation measures against SARS-CoV-2 infection on sexual health. AIDS Behav. 2020;1(8):1-2259. https://doi.org/10.1 007/s10461-020-02853-x.

14. Balestri R, Magnano M, Rizzoli L, Infusino SD, Urbani F, Rech G. STIs and the COVID-19 pandemic: the lockdown does not stop sexual infections. J Eur Acad Dermatol Venereol. 2020:jdv.16808. https://doi.org/10.1111/jdv.16808.

15. Tang K, Gaoshan J, Ahonsi B. Sexual and reproductive health (SRH): a key issue in the emergency response to the coronavirus disease (COVID-19) outbreak. Reprod Health. 2020;17(1):59. https://doi.org/10.1186/s12978-0200900-9.

16. Sanchez TH, Zlotorzynska M, Rai M, Baral SD. Characterizing the impact of COVID-19 on men who have sex with men across the United States in April, 2020. AIDS Behav. 2020;24(7):2024-32. https://doi.org/10.1007/s10461-020-02 894-2.

17. Jenness SM, Le Guillou A, Chandra C, Mann LM, Sanchez T, Westreich D, et al. Projected HIV and bacterial STI incidence following COVID-related sexual distancing and clinical service interruption. medRxiv. 2020. https:// doi.org/10.1101/2020.09.30.20204529

18. Berzkalns A, Thibault CS, Barbee LA, Golden MR, Khosropour C, Kerani RP. Decreases in reported sexually transmitted infections during the time of COVID-19 in King County, WA: decreased transmission or screening? Sex Transm Dis. 2021;48(8S):S44-9. https://doi.org/10.1097/OLQ.00000000000014 63.

19. Chow EPF, Hocking JS, Ong JJ, Phillips TR, Fairley CK. Sexually transmitted infection diagnoses and access to a sexual health service before and after the National Lockdown for COVID-19 in Melbourne, Australia. Open Forum Infect Dis. 2021;8(1). https://doi.org/10.1093/ofid/ofaa536.

20. Simões D, Stengaard AR, Combs L, Raben D. Impact of the COVID-19 pandemic on testing services for HIV, viral hepatitis and sexually transmitted infections in the WHO european region, march to august 2020. Eurosurveillance. 2020;25(47):2001943. https://doi.org/10.2807/1560-7917.ES.2 020.25 .47 .2001943

21. Alessandra L, Francesca M, Maria Gabriella D, Massimo G, Antonio C, Mauro Z. Is COVID-19 affecting the epidemiology of STIs? The experience of syphilis in Rome. Sex Transm Infect. 2020; sextrans-2020-054543. https://doi. org/10.1136/sextrans-2020-054543.

22. Williamson DA, Chen MY. Emerging and reemerging sexually transmitted infections. N Engl J Med. 2020;382(21):2023-32. https://doi.org/10.1056/ NEJMra1907194.

\section{Publisher's Note}

Springer Nature remains neutral with regard to jurisdictional claims in published maps and institutional affiliations. 